\title{
COMPARISON OF ANTIBACTERIAL ACTIVITIES LEAVES EXTRACTS OF CERBERA MANGHAS AND LEAVES EXTRACTS OF AZADIRACHTA INDICA AGAINST KLEBSIELLA PNEUMONIAE
}

\author{
MUHAMMAD YANIS MUSDJA ${ }^{1 *}$, MARKHAMATUL AENI ${ }^{1}$, IRA DJAJANEGARA ${ }^{2}$ \\ ${ }^{1}$ Department of Pharmacy, State Islamic University, Syarif Hidayatullah, Jakarta, Indonesia, ${ }^{2}$ Department of Biology, Indonesian Institute of \\ Sciences, PUSPITEK, Serpong, Banten, Indonesia. Email: myanis88@gmail.com
}

Received: 23 April 2018, Revised and Accepted: 29 August 2018

\section{ABSTRACT}

Objective: This study aims to determine the potential of neem (Azadirachta indica, Juss) leaves and sea mango (Cerbera manghas, Linn.) leaves against Klebsiella pneumonia.

Methods: Hexane and methanol extracts of neem leaves (A. indica, Juss) and hexane and butanol extracts of sea mango leaves ( $C$. manghas, Linn.) were tested antibacterial against $K$. pneumonia using paper disc and dilution methods, measured the inhibition zone diameter, minimum inhibitory concentration (MIC), and minimum bactericidal concentration (MBC), as a comparison used ampicillin.

Results: The MIC values for the butanol extract and hexane extract of sea mango leaves against K. pneumoniae were 1.124276 and 1.45958 mg/mL, respectively. While the $\mathrm{MBC}$ value of both of them had the same value, i.e. $2 \mathrm{mg} / \mathrm{ml}$. The hexane and methanol extracts of neem leaves did not have potentially against the growth of $K$. pneumonia.

Conclusion: Based on the results of this study have been obtained, that extracts butanol and hexane extract of leaves of sea mango ( $C$. manghas, Linn.) have antibacterial activity strong enough against $K$. pneumonia, where, extracts butanol leaves of sea mango has antibacterial activity that is more powerful than the extract hexane leaf sea mango, while the methanol extract and hexane extracts of neem (A. indica, Juss) leaves have weak activity against $K$. pneumonia

Keywords: Antibacterial, Cerbera manghas, Azadirachta indica, Klebsiella pneumonia.

(C) 2018 The Authors. Published by Innovare Academic Sciences Pvt Ltd. This is an open access article under the CC BY license (http://creativecommons. org/licenses/by/4. 0/) DOI: http://dx.doi.org/10.22159/ajpcr.2018.v11s3.30030

\section{INTRODUCTION}

Mastitis is an inflammation of the mammary gland characterized by physical, chemical, bacteriological, and cytological changes in milk. Pathological changes in glandular tissues of the udder and effects on the quality and quantity of milk have been observed [1]. This disease is mainly caused by microorganisms usually bacteria, including Gram-negative and Gram-positive bacteria, mycoplasmas, yeasts, and algae [2]. Bacterium Klebsiella pneumoniae is a major cause of illness nipple mastitis in dairy cows and other mammals in Indonesia [3]. Mastitis disease in dairy cattle is very detrimental because it can reduce milk dairy cows production up to $30 \%[4,5]$.

On the other hand, milk and milk products have the potential to transmit pathogenic organisms to humans. All the nutritional components that make milk and milk products an important part of the human diet also support the growth of pathogenic organisms. Early in this century, it was discovered that milk can transmit tuberculosis, brucellosis, diphtheria, scarlet fever, and Q fever to humans. Fortunately, over the decades, the threat of these diseases and the incidence of outbreaks involving milk and milk products have been greatly reduced due to improved sanitary of the milk production practices and pasteurization technique. However, a variety of microorganisms still contribute to illnesses and disease outbreaks $[6,7]$.

One of the bacteria that cause mastitis that is already resistant to methicillin is Staphylococcus aureus. Strain of $S$. aureus resistant to $\beta$-lactam antibiotics is known as methicillin-resistant $S$. aureus (MRSA). The MRSA strains have been observed to multidrugresistant, such as aminoglicosides, macrolides, lincosamides, streptogramins, and tetracyclines which are often used in the treatment of mastitis $[8,9]$.
One alternative to prevent mastitis is to use antimicrobials from nature to minimize the side effects of chemical treatment.

Azadirachta indica. Juss commonly known as neem has become cynosure of modern medicine. More than 140 compounds of neem have been isolated from different parts, such as flowers, seeds, fruits, roots, and barks have been used traditionally for the treatment of inflammation, infections, fever, skin disease, and dental disorder. Neem leaf and its constituent have been demonstrated to exhibit antibacterial, antifungal, antimalarial, antiviral, anticarcinogenic, antioxidant, antiulcer, antiinflammatory, antihyperglycemic, and for immunomodulatory $[10,11]$. Cerbera manghas Linn. in traditional medicine, in the Asia Pacific region is used to treat fever, malaria, pain, diabetes, and gastrointestinal ailments, including skin and ectoparasitic diseases [12].

\section{MATERIALS AND METHODS}

\section{Materials}

Isolate of bacteria $K$. pneumoniae, obtained from the Laboratory of Microbiology, Indonesian Institute of Sciences, Cibinong Bogor. Indonesia. Medium Tryptic Soy Broth (Pronadisa), bacteriological agar (Oxoid), Sea mango leaves, and neem leaves were obtained from Research Institute for Spices and Medicinal Plants, Bogor, Indonesia. Ethanol, hexane, butanol, and methanol were obtained from E-Merck. Ampicillin antibiotic (Zigma). glassware, microbiological culture media, chemicals and materials that commonly used in microbiology laboratories.

\section{Methods}

Preparation of hexane and methanol extract of neem and leaves the hexane and butanol extract sea mango leaves were carried out based on harborne method [13], as shown in Scheme 1. 


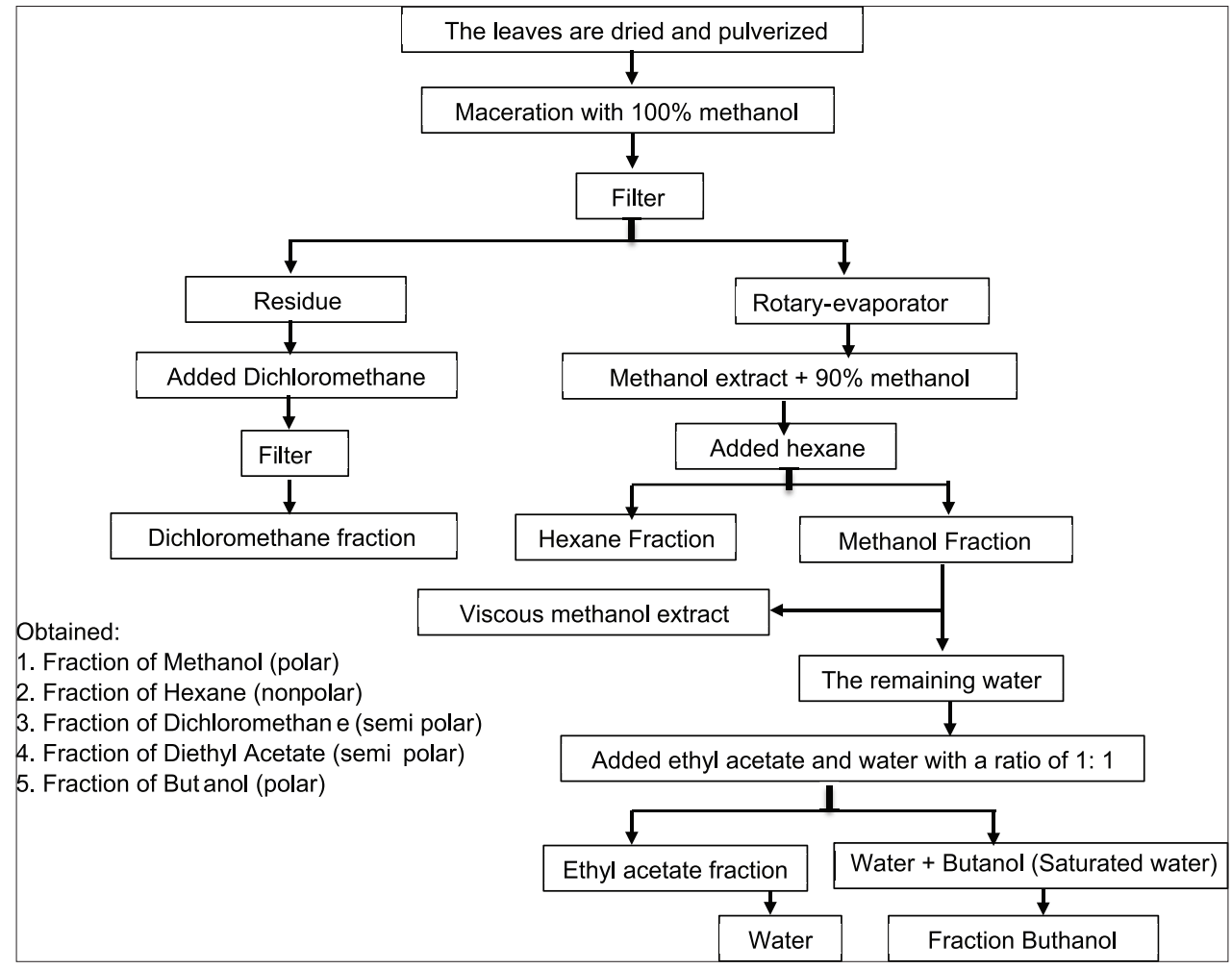

Scheme 1: Preparation process of solution of methanol and hexane extract of neem leaves and hexane and butanol leaves extract of sea mango

Phytochemical screening for hexane and methanol extract of neem and leaves the hexane and determination The growth curve of K. pneumoniae bacteria was performed in tryptic soy broth medium incubated at $37^{\circ} \mathrm{C}$ and agitation at $120 \mathrm{rpm}$ based on absorbance value butanol extract sea mango leaves was done by the Farnsworth method.

Determination of inhibition zone diameter (IZD) of hexane and methanol extract of neem leaves and the hexane and butanol extract of sea mango leaves against K. pneumoniae was done by agar diffusion method, using the paper disc.

Determination minimum inhibitory concentration (MIC) of hexane and methanol extract of neem leaves and the hexane and butanol extract of sea mango leaves which can inhibit the growth of test bacteria was done by microdilution method using a test tube.

The minimum bactericidal concentration (MBC) test was determined using a series of steps, undertaken after a MIC test has been completed. This determination was done by dilute the MIC results and incubated at $39^{\circ} \mathrm{C}$ for $24 \mathrm{~h}$, then counted the number of growing colonies.

\section{RESULTS AND DISCUSSION}

Simplicia leaves of sea mango (C. manghas Linn.) and leaves of neem ( $A$. indica, Juss) in this study after being cleaned, dried, and powdered. The extraction was done gradually using the method of extraction of Harborne method, which was multilevel extraction using different solvent of polarity. The purpose of this gradual extraction was to draw and separate the organic compounds contained in the simplicia by virtue of their polarity [13]. The results of this extraction were used to determine the antibacterial activity against $K$. pneumoinae. Then, on each extract was examined the chemical content qualitatively.

The results of phytochemical screening show that there were some differences in the content of the 4 test preparations consisting of butanol extract and hexane extract of sea mango, methanol extract and hexane extract of neem, while the chemical content is not tested in the table above, because according to the literature, the extract does not contain any chemical compounds that are not tested [14-16].

From the results of phytochemical screening were obtained results as shown in Table 1.

In this research, the result of the growth curve of $K$. pneumoniae showed that there was only two growth phases, namely the logarithmic phase and the stationary phase. In the growing curve there is no phase of adaptation but directly enter the stationary phase. The growth of this bacteria can be seen from the change of absorbance value obtained after the measurement at different minutes. Based on the curve, then determined mid-log phase. Mid-log phase is shown in 180 min with the absorbance of 0.942 and speed of 0.0066 per min (Tables 2 and 3).

To determine the concentration hexane extract of sea mango leaves which is the equivalence to antibiotic, based on IZD extract hexane of sea mango against $K$. pneumoniae determined by the equation: $y=9.110 x-71,26$ (Fig. 1) [17].

Based on the above curve, it can be seen that $250000 \mu \mathrm{g} / \mathrm{ml}$ of sea mango hexane extract is equivalent to $88,165 \mu \mathrm{g} / \mathrm{ml}$ ampicillin antibiotic, $500000 \mu \mathrm{g} / \mathrm{ml}$ sea mango hexane extract equivalent to $92.72 \mu \mathrm{g} / \mathrm{ml}$, and $1,000,000 \mu \mathrm{g} / \mathrm{ml}$ sea mango hexane extract equivalent to $101,83 \mu \mathrm{g} / \mathrm{ml}$ as shown in Table 4.

Based on IZD was found equivalence between antibiotic ampicillin with extract butanol of sea mango against K. pneumonia on as shown in Fig. 2.

Based on the equation, $y=5.825 \mathrm{x}-34.62$ contained in Fig. 2 , obtained the results in Table 5 .

Based on IZD was found equivalence between antibiotic ampicillin with extract hexane of neem against K. pneumonia on as shown in Fig. 2. 
Table 1: Results of phytochemical screening leaf extract sea mango and neem

\begin{tabular}{|c|c|c|c|c|c|}
\hline No & Chemical content & Butanol extract sea mango & Hexane extract sea mango & Methanol extract neem & Hexane extract neem \\
\hline 1 & Alkaloids & - & - & + & + \\
\hline 2 & Flavonoids & + & + & + & + \\
\hline 3 & Saponin & + & - & + & - \\
\hline 4 & Tannin & + & - & + & - \\
\hline 5 & Quinon & + & - & Not tested & Not tested \\
\hline 6 & Triterpenoid & - & + & + & - \\
\hline 7 & Coumarin & - & + & Not tested & Not tested \\
\hline 9 & Glycoside & Not tested & Not tested & + & + \\
\hline 10 & Steroid & Not tested & Not tested & + & - \\
\hline 11 & Phenolic & Not tested & Not tested & + & - \\
\hline
\end{tabular}

Table 2: The average IZD value of hexane and butanol extract of sea mango leaves against bacteria K. pneumoniae at several concentrations $(\mu \mathrm{g} / \mathrm{ml})$

\begin{tabular}{|c|c|c|c|c|c|c|c|c|c|}
\hline Petri dish concentration & M1 30 & M2 40 & M3 55 & H1 250 & H2 500 & H3 1000 & B1 250 & B2 500 & B3 1000 \\
\hline Average of diameter & 11 & 12.5 & 13.5 & 17.5 & 18 & 19 & 21 & 23.5 & 25 \\
\hline
\end{tabular}

M: Methicillin, H: Hexane extract of neem, B: Buthanol extract of neem, IZD: Inhibition zone diameter, K. pneumonia: Klebsiella pneumonia

Table 3: The average IZD value of mathanol and butanol extract of neem leaves against bacteria $K$. pneumoniae at several concentrations $(\mu \mathrm{g} / \mathrm{ml})$

\begin{tabular}{llllllllll}
\hline Petri dish concentration & M1 30 & M2 40 & M3 55 & MOH1 250 & MOH2 500 & MOH3 1000 & B1 250 & B2 500 & B3 1000 \\
\hline Average of diameter & 10 & 12 & 13.5 & 6 & 6 & 6 & 6 & 6 & 6 \\
\hline
\end{tabular}

M: Methicillin, MOH: Methanol extract of neem, B: Butanol extract of neem, IZD: Inhibition zone diameter, K. pneumonia: Klebsiella pneumonia

Table 4: Table concentration equivalence between antibiotic ampicillin with extract hexane of sea mango against $K$. pneumonia on IZD

\begin{tabular}{|c|c|c|c|}
\hline Extract concentration $(\mu \mathrm{g} / \mathrm{ml})$ & 250000 & 500000 & 100000 \\
\hline IZD of extract $(\mathrm{mm})$ & 17.5 & 18 & 19 \\
\hline $\begin{array}{l}\text { Equivalent concentrations of } \\
\text { antibiotics }(\mu \mathrm{g} / \mathrm{ml})\end{array}$ & 88.165 & 92.72 & 101.83 \\
\hline
\end{tabular}

Table 5: Table concentration equivalence between antibiotic ampicillin with extract butanol of sea mango against

\section{K. pneumonia on IZD}

\begin{tabular}{llll}
\hline Extract concentration $(\mu \mathrm{g} / \mathrm{ml})$ & 250000 & 500000 & 1000000 \\
Inhibition zone diameter $(\mathrm{mm})$ & 21 & 23.5 & 25 \\
Equivalence antibiotic $\mathrm{mg} / \mathrm{ml}$ & 87.7 & 102.3 & 111 \\
\hline
\end{tabular}

IZD: Inhibition zone diameter, K. pneumonia: Klebsiella pneumonia

Based on the equation, $y=5.129 x-17.03$ contained in Fig. 3, obtained the results as shown in Table 6.

From Table 6, the hexane extract of the neem leaves shows its action against K pneumonia from low, medium, and high doses having a partial IZD.

To determine the concentration methanol extract of neem leaves which is the equivalence to antibiotic, based on IZD extract methanol of neem against K pneumoniae determined by the equation: $\mathrm{y}=6.567 \mathrm{x}-36.61$

Based on the equation, $y=6.567 x-36.61$ contained in Fig. 4, obtained the results as shown in Table 7.

In the determination IZD of hexane extract and methanol leaves neem. The neem leaves have provided partial resistance zones to the test bacteria; this is because the antibacterial concentration that diffuses to the area decreases, which is insufficient to inhibit all bacterial growth [18]. The obstacle zone formed in the antibacterial
Table 6: Table concentration equivalence between antibiotic ampicillin with extract hexane of neem against $K$. pneumonia on IZD

\begin{tabular}{llll}
\hline Extract concentration $(\mu \mathrm{g} / \mathrm{ml})$ & 250000 & 500000 & 1000000 \\
Diameter of zone inhibition $(\mathrm{mm})$ & 6 & 6 & 6 \\
Equivalence antibiotic & 13.74 & 13.74 & 13.74 \\
\hline
\end{tabular}

IZD: Inhibition zone diameter, K. pneumonia: Klebsiella pneumonia

Table 7: Concentration equivalence between antibiotic ampicillin with extract methanol of neem against $K$. pneumonia on IZD

\begin{tabular}{llll}
\hline Extract concentration $(\mu \mathrm{g} / \mathrm{ml})$ & 250000 & 500000 & 1000000 \\
Diameter of zone inhibition $(\mathrm{mm})$ & 6 & 6 & 6 \\
Equivalence antibiotic $(\mathrm{mg} / \mathrm{ml})$ & 2.792 & 2.792 & 2.792 \\
\hline
\end{tabular}

IZD: Inhibition zone diameter, K. pneumonia: Klebsiella pneumonia

power test is divided into two, i.e., there is a total and partial. The total obstacle zone when the area around the disc is clear, meaning the bacteria is really sensitive to the concentration of the extract given. Partial obstacle zone when there is a zone of resistance formed around the disc there were still some colonies of germs. Therefore, the hexane and methanol extracts of the neem leaves provide a partial obstruction zone, so it was not followed in the measurement of MIC and MBC. While that was continued only for hexane extract and butanol of Bintaro leaves, because it has given IZD and has MIC and MBC $[18,19]$.

The result of MIC and MBC of hexane extract and butanol extract of sea mango leaves against K. pneumoniae was found as shown in Table 8.

The MIC values for the butanol extract of sea mango leaves to $K$. pneumoniae were $1.124276 \mathrm{mg} / \mathrm{ml}$ whereas in the hexane extract of the mango leaves to $K$. pneumoniae bacteria was shown at concentrations of $1.345958 \mathrm{mg} / \mathrm{ml}$, which at the concentrations were the lowest concentrations that could inhibit the growth bacteria. 


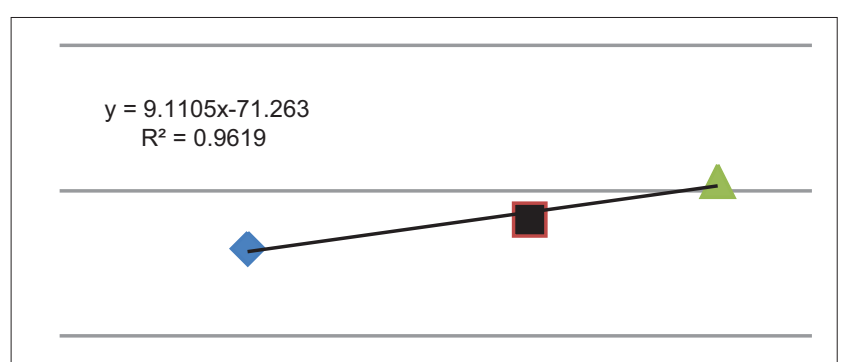

Fig. 1: The relationship of concentration between antibiotic ampicillin with extract hexane of sea mango against Klebsiella pneumonia on the diameter of zone inhibition

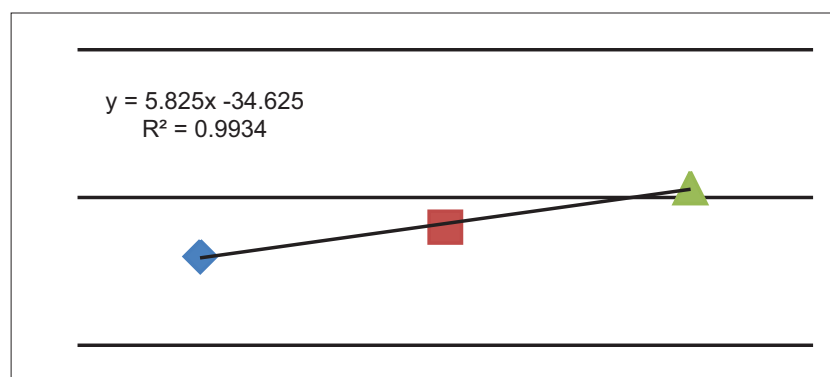

Fig. 2: The relationship of concentration between antibiotic ampicillin with extract butanol of sea mango against Klebsiella pneumonia on inhibition zone diameter

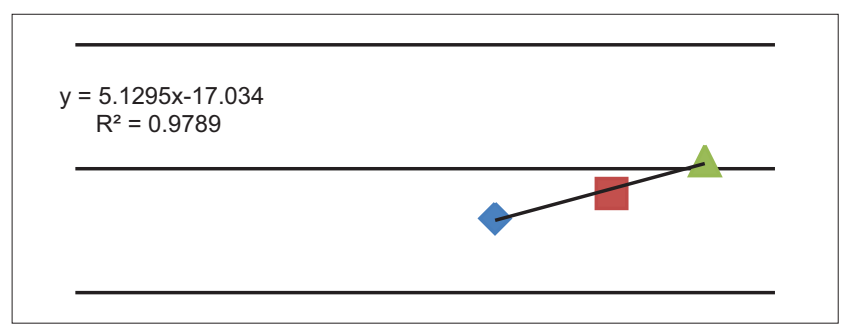

Fig. 3: The relationship of concentration between antibiotic ampicillin with extract hexane of neem against Klebsiella pneumonia on the diameter of zone inhibition

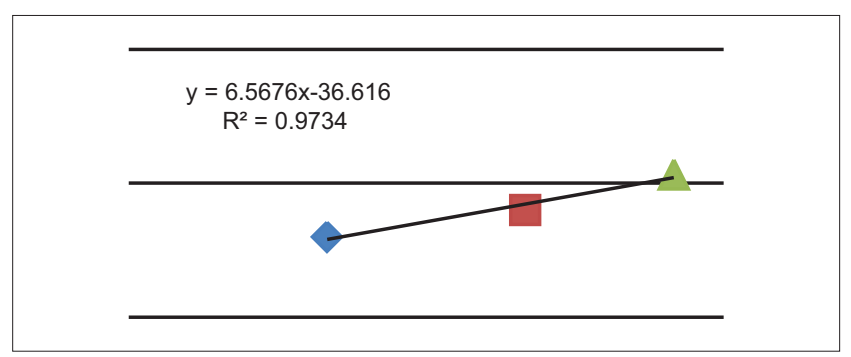

Fig. 4: The relationship of concentration between antibiotic ampicillin with extract methanol of neem against Klebsiella pneumonia on inhibition zone diameter

Butanol extract of sea mango leaves and hexane extract of sea mango leaves have the same MBC value that was $2 \mathrm{mg} / \mathrm{ml}$.

\section{CONCLUSION}

Based on the results of this study have been obtained, that extracts butanol and hexane extract of leaves of sea mango (C. manghas Linn.) have antibacterial activity strong enough against $K$. pneumonia, where extracts butanol leaves of sea mango have antibacterial activity that
Table 8: The result of MIC and MBC of hexane extract and butanol extract of sea mango leaves against Klebsiella pneumoniae

\begin{tabular}{llll}
\hline No. & $\begin{array}{c}\text { Concentration } \\
(\mathbf{m g} / \mathbf{m l})\end{array}$ & \multicolumn{2}{c}{ Extract sea mango leaves } \\
\cline { 3 - 4 } & & Hexane extract & Butanol extract \\
\hline 1 & 0.5 & + & + \\
2 & 1 & $+(\mathrm{MIC})$ & $+(\mathrm{MIC})$ \\
3 & 2 & $-(\mathrm{MBC})$ & $-(\mathrm{MBC})$ \\
4 & 4 & - & - \\
5 & 8 & - & - \\
6 & 16 & - & - \\
7 & 20 & - & - \\
8 & 32 & - & - \\
9 & 64 & - & - \\
10 & 128 & - & - \\
11 & 256 & - & - \\
\hline
\end{tabular}

+: There was bacterial growth -: There was no bacterial growth. MIC: Minimum inhibitory concentration, MBC: Minimum bactericidal concentration

is more powerful than the extract hexane leaf sea mango, while the methanol extract and hexane extracts of neem (A. indica, Juss) leaves have weak activity against $K$. pneumonia.

\section{REFERENCES}

1. Amir HA. Mastitis in housed dairy buffaloes: Incidence, etiology, clinical finding, antimicrobial sensitivity and different medical treatment against E. coli mastitis. Life Sci J 2013;10:532-8.

2. Zadoks RN, Middleton JR, McDougall S, Katholm J, Schukken YH. Molecular epidemiology of mastitis pathogens of dairy cattle and comparative relevance to humans. J Mammary Gland Biol Neoplasia 2011;16:357-72.

3. Estuningsih S. The Pathogenicity of Subclinical Mastitis in Dairy Cows: Histological Approach of Mastitis Subclinical Due to Infection of Streptococcus agalictiae, Hemaglutinin Positive in Mice. Ph.D. Dissertation, Faculty of Veterinary Medicine, Bogor Agricultural Institute. Indonesia; 2002.

4. Izquierdo AC, Liera JE, Cervantes RE, Castro JF, Mancera EA, Crispín RH, et al. Production of milk and bovine mastitis. J Adv Dairy Res 2017:2:1-4

5. Seegers H, Fourichon C, Beaudeau F. Production effects related to mastitis and economics in dairy cattle herds. J Vet Res 2003;34: 475-91.

6. Hameed KG, Sender G, Kossakowska AK. Public health hazard due to mastitis in dairy cows. J Anim Sci Papers Rep 2006;25:73-85.

7. Kheira G, Abdellatif N. Impact of subclinical mastitis on the health of the mammary gland. J Glob Vet 2014;12:193-6.

8. Wang Y, Wu CM, Lu LM, Ren GW, Cao XY, Shen JZ, et al. Macrolidelincosamide-resistant phenotypes and genotypes of staphylococcus aureus isolated from bovine clinical mastitis. Vet Microbiol 2008;130:118-25.

9. Idriss SE, Foltys V, Tančin V, Kirchnerova K, Tančinová D, Zaujec K. Mastitis pathogens and their resistance against antimicrobial agents in dairy cows in Nitra, Slovakia. J Anim Sci 2014;47:33-8.

10. Biswas $\mathrm{K}$, Ishita $\mathrm{C}$, Ranajit KB, Uday B. Biological activities and medicinal properties of neem (Azadirachta indica, Juss). J Technol Dev 2002;8:23-8

11. Subapriya R, Nagini S. Medicinal properties of neem leaves: A review. Curr Med Chem Anticancer Agents 2005;5:149-6.

12. Wiart C. Medicinal Plants of Asia and Pacific. Boca Raton: CRC Press/ Taylor and Francis; 2006.

13. Harbone AJ. Phytochemical Methods, a Guide to Modern Techniques of Plant Analysis. Netherlands: Publisher Springer; 1998.

14. Xiaopo Z, Yue-hu P, Ming-sheng L, Sheng-li K, Jun-qing Z. Chemical constituents from the leaves of Cerbera manghas. Asian Pac J Trop Med 2010;3:109-111.

15. Hossain MA, Islam MA, Sarker S, Rahman M, Siraj MA. Assessment of phytochemical and pharmacological properties of ethanolic extract of Cerbera manghas L. leaves. Int Res J Pharm 2013;4:120-3

16. Galeane MC, Martins CH, Massuco J, Bauab TM, Sacramento LV. 
Phytochemical screening of Azadirachta indica A. Juss for antimicrobial activity. Afr J Mic Res 2017;11:117-22.

17. Alexander JW, Good RA. Effect of antibiotics on the bactericidal activity of human leukocytes. J Lab Clin Med 1968;71:971-83.
18. Lorian V. Antibiotic in Laboratory Medicine. $2^{\text {nd }}$ ed. London, Baltimore: Williams and Wilkins Co.; 1980

19. WHO. Antimicrobial Resistance: Global Report on Surveillance, 2014. p. $12-30$ 